\title{
Pharmaceutical and Cosmeceutical Marketing and Advertising in Malaysia: An Overview of Current Governing Laws and Regulations
}

\author{
Mohamed Azmi Ahmad Hassali ${ }^{1}$ and Sadia Shakeel ${ }^{1,2 *}$ \\ ${ }^{1}$ Discipline of Social and Administrative Pharmacy, School of Pharmaceutical Sciences, University Sains Malaysia, Malaysia \\ ${ }^{2}$ Faculty of Pharmaceutical Sciences, Dow University of Health Sciences, Pakistan \\ *Corresponding author: Sadia Shakeel, Discipline of Social and Administrative Pharmacy, School of Pharmaceutical \\ sciences, University Sains Malaysia, Malaysia
}

\begin{abstract}
ARTICLE INFO
Received: March 03, 2020

Published: 㓞 March 10, 2020

Citation: Mohamed Azmi A H, Sadia Shakeel. Pharmaceutical and Cosmeceutical Marketing and Advertising in Malaysia: An Overview of Current Governing Laws and Regulations. Biomed J Sci \& Tech Res 26(3)2020. BJSTR. MS.ID.004357.
\end{abstract}

Abbreviations: GMP: Good Manufacturing Practices; MAB: Medicine Advertisements Board; MASA: Medicines Advertisement and Sale Act; MDTCA: Ministry of Domestic Trade \& Consumer Affairs; DCA: Drug Control Authority

\section{ABSTRACT}

The pharmaceutical business of Malaysia has been encountering dynamic development throughout the years. Sales and advertising need obligations of pharmaceutical organizations to spread the product information and materials through a precise regulatory pathway of advancing the sales of products. The pharmaceutical manufacturing hub in Malaysia is under the supervision of the Ministry of Health $(\mathrm{MoH})$ of Malaysia. An execution of various laws and the establishment of regulating authorities have been done to govern the pharmaceutical business and protecting the community. While the laws are executed, the legislature or related specialists should watch out for the present medicinal issues to pass judgment on the viability of the current laws in overseeing the pharmaceutical sales and advertisement. The public should be exposed to the advertisements which help the consumers to settle on level-headed choices on the utilization of medications without confounding, misdirecting and beguiling cases. However, such activities are commendable if they are following the enactment and rules provided by the respective authority.

Keywords: Marketing; Advertising; Cosmeceutical; Laws; Pharmacy; Malaysia; Healthcare

\section{Introduction}

A set of rules for society is known as law; intended to treat everyone equitably and to protect the fundamental rights and independence. Laws are vital to ensure that a person within the jurisdiction commanding what is correct and prohibiting what is incorrect. Public laws manage matters that influence society in general, though private law manages the connections between individuals in society [1]. In the pharmacy context, pharmacy laws provide the rules and guidelines for practicing pharmacy and describe the best approach to deal with specific pharmacy practice situations [2]. From the perspective of pharmacy, 'Advertisement' under the 1956 Act is defined as all forms of communiqué methods that intend to promote a particular product or service. Advertising and promotional of medicines are allowed as long as they are obeying guiding principles provided by the legislative authority to make sure that public safety and well-being are not getting compromised. Currently, medicine advertising is regulated under the Medicines (Advertisement and Sale) Act (MASA) 1956 in Malaysia [3]. Medicine Advertisements Board (MAB) plays an essential role to give or withdraw approval for an advertisement, revise the policies or guidelines and obliterate any act or advertisement which could bring about objectionable contemplations to the observers [4]. MAB's approval is needed to promote non-prescription substances 
which can be used as medications, appliances or other therapies. Any deceptive or unverified statement likely to induce medically unjustifiable drug use should be avoided in the advertisements [5]

\section{Laws Governing Marketing and Advertising}

\section{Sale of Drugs Act 1952}

Sale of Drugs Act 1952 is an act relates to the selling of pharmaceutical drugs. In consonance with this act, the Yang diPertuan Agong may employ several analysts, while the Chief Minister may hire drug inspectors and officers and assign their job descriptions. Any officers or inspectors may mark, seal, or else secure, calculate, measure or weigh any drug appear to be conflicting to this act [6]. They may also get hold of any drug that is deleterious to healthiness and abolish any drug that is found to be putrefied. Under section 10, an individual involves in sells of any adulterated drug and do not notify purchaser; sells any drug that contains an incorrect or ambiguous statement, brand, word or mark on the packaging; sells any drug that contains addition of substance that is prohibited; sell any drug that contains a larger ratio of any substance than that which is permitted; sell any drug contains denatured alcohol, methyl alcohol or isopropyl alcohol intended for internal use; sells any drug that is not containing the quality of medication claimed by customer are all commits an offense $[7,8]$.
As reported by The Star Online, recently the ministry of Pharmacy Enforcement Division and the Public Health Development Division inspected 78 premises in an operation and seized 66,988 e-cigarette liquids suspected to contain nicotine. Nicotine is considered as one of the Group C poisons. Any preparation which contains nicotine shall be registered with the Drug Control Authority as stated in the Sale of Drugs Act 1952 and Control of Drugs and Cosmetics Regulations 1984. The Director-General of Health, Dr. Noor Hisham Abdullah said that the offenders are punished under Section 12 (1) and 13 of the Sale of Drugs Act 1952.

According to section 12, any person who commits an offense for the first time can be fined not greater than RM 25,000 or be imprisoned not more than three years or to both. For a subsequent offense, he can be fined not more than RM 50,000. On the other side, anybody corporates with a person who commits an offense can be fined not more than RM 50,000 for the first time, and for a subsequent offense, it can be fined not more than RM100, 000. Notifications include name, occupation, place of business, fine, forfeiture and the nature of offense shall be published in newspapers if the court order to do so. The cost of such publication is charged on an individual who commits offense in contradiction of this act as a civil debt based on section 14 [9].

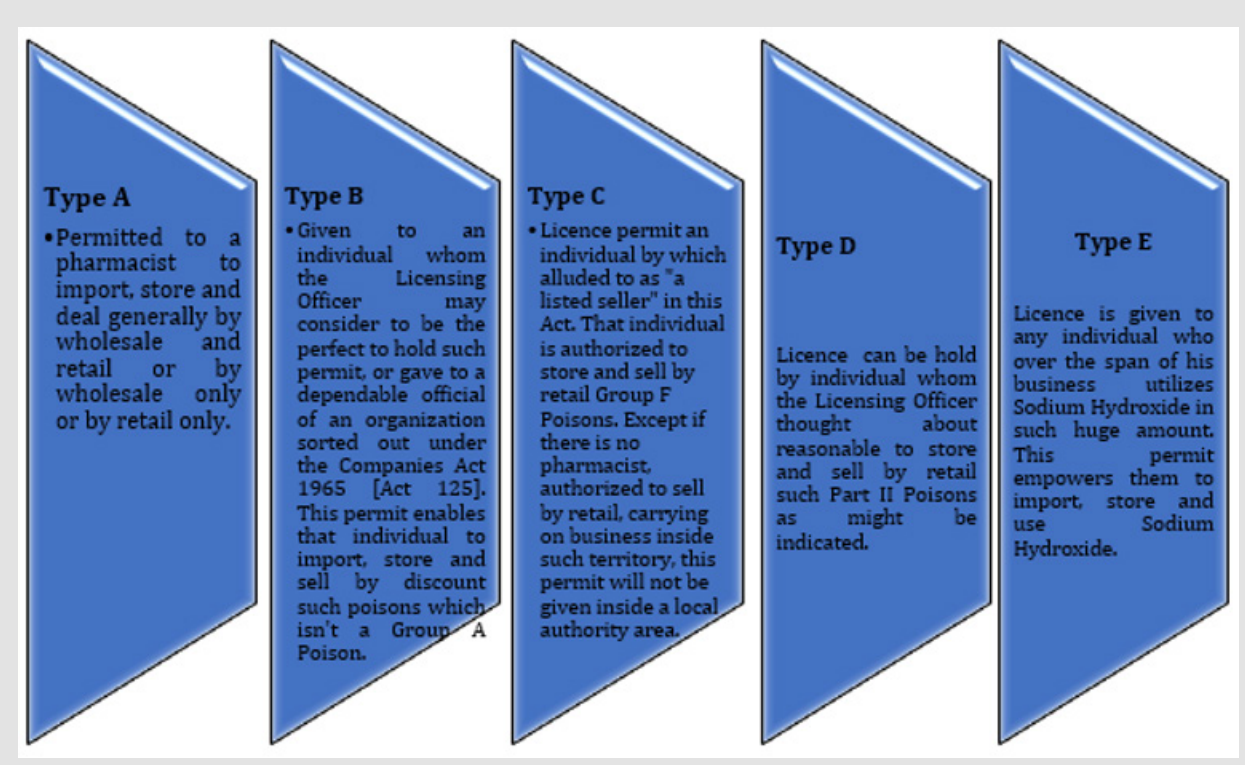

Figure 1: License involves in pharmaceutical sales in Malaysia.

Licenses Involving in Sales: There are 5 categories of licenses included in sales (Figure 1) and each license will be considered in the structure endorsed appropriate to the kind of such authorization and it will express the name of the issued individual and the premises on which any sale or use might be affected and the legality of the permit. Each license will be needy to such terms and conditions and not opposing this Act or any guidelines made under it. The Licensing Officer may decline to give any such permit or may drop any such license that has been given if that any individual wronged by the refusal of the Licensing Officer to give a permit or by the crossing out of a permit. This may speak to the Minister whose choice will be conclusive. The license will be only for the holder of the permit and can't be transferable to someone else. Just the individual who named in the permit is allowed to sell poison or generally, the toxic substance must be sold under his own supervision. Something else, the Licensing Officer may 
correct the location of the premises at which the licensee carries on the business or calling in regard to which he is authorized on the permit [10].

\section{Control of Drugs and Cosmetics Regulations (1984)}

Control of drugs and cosmetics regulations can be divided into five parts. Part 1 relating to preliminary; part 2 relating to the drug and control authority; part 3 relating to registration and licensing; part 4 relating to manufacturing of registered products or notified cosmetics and part 5 relating to miscellaneous. A product is defined as "a drug is a dosage unit and being administered to human beings or animals for the treatment purpose". It is also described as a drug that can be utilized as an ingredient needed for medical preparation [11]. In agreement with this act, nobody can import, possess, supply, sell, manufacture or administer any product that is unregistered under section 7 (a). Nobody can supply false or ambiguous info to the authority during the claim of product registration under section 8 (9). The Secretary will keep a register of the product which must contain the name of the enlisted product, the quantity of active ingredients, address and name of a producer, address and the name of the product registration holder, product listing number or item registration number and date of issue or expiry date if present [12]. Other than that, any importer or licensed wholesaler shall keep all records of each transaction for a period not less than 5 years (section 27).

The holder of a registered product shall notify directly the Director of Pharmaceutical Services when finding out incompatible reactions of such product under (section 28). The Director of Pharmaceutical Sciences may give direction or guiding principle in black and white as regards product efficacy, quality and safety; labeling; storage; retailing; promotion of the sale; manufacturing; change of substances of products; transfer of license; recall or discarding of product; clinical trials and certain records and statistical figures. Any person who disobeys the directions or guidelines given by the Director of Pharmaceutical Sciences commits an offense [13].

For a registered cosmetic product, the manufacturer shall establish a quality control department, which controls all materials, stability, and quality of the final registered products or cosmetics in accordance with this act. A proper record of each batch of such products or cosmetics distribution shall be kept [14].

\section{Dangerous Drugs Act 1952}

Dangerous Drugs Act 1952 is the regulation of the importation, exportation, production, sale, and usage of certain dangerous drugs and substances which contain 50 sections. Drug Enforcement Officer may be employed by Yang di Pertuan Agong for the determinations of this Act. Section 4 to 6 states about the restriction on importation, exportation, possession or planting of raw opium, poppy-straw or cannabis, coca leaves otherwise in agreement with authorization. The Minister might regulate the controlling, prohibiting and confining the cultivation, ownership, manufacture, trade, and delivery of raw opium, coca leaves, poppystraw or cannabis. Section 9 stated that any person who export from or import into Malaysia, possess or involve in manufacturing or sell prepared opium shall be liable for conviction. The restriction of using any premise or utensils for making, selling, smoking or consumption of prepared opium also has been stated in Section 10 of this Act [15-17]. Dangerous Act 1952 also restricts the importation, exportation, administration to others and also selfadministration of any dangerous drug indicated in Parts III, IV, and $\mathrm{V}$ of the First Schedule.

Any hazardous drug in transit shall not be brought to Malaysia and shall not be subjected to change that may alter its nature which have been mentioned in Section 23 of this Act unless in accordance with authorization important regulations made by Minister in Section 16 in order to control the production, sale, custody, and distribution of certain drug and to prevent inappropriate usage of the dangerous drugs. Furthermore, no person shall involve trafficking in a dangerous drug [17]. Regulations related to inspection, search, arrest, seizure and examination of the arrested person or medical officer are mentioned from Section 27 until Section 31. Magistrate and Justice of the Peace have power for inspection and seizure upon information or premises such as dangerous drug, book, article, utensils or document that is liable to forfeiture under section 27 of Dangerous Act 1952. Some specified people such as Public Prosecutor has the power to intercept communication if he considers that it is likely to contain any information or an act preparatory to or for the purpose of committing an offense against this Act. A person who obstructs the inspection or search shall be guilty of an offense against this Act and liable for conviction. For the prosecution, it may be conducted by certain people stated in Section 42. Rewards may be given to any officer or other people for services made under this Act [18].

Dangerous Act also mentioned about the false declaration or statement or document in Section 32. Any abetment or attempt to commit an act preparatory to any offense under this Act shall be guilty of such offense and liable to the punishment. In Section 37, presumption and its application have been stated and some rules about the admission of the statement in evidence are listed. Next, if any ship or aircraft is used for unlawful import or export, the owner would be liable to a fine. This section also discussed the power of the Court in respect of drug dependants below the age of eighteen. Generally, if there is no penalty specifically provided, the person shall be liable to a fine, not more than 5000 ringgit or to the custody of less than two years or to both [17].

\section{Poison Act 1952}

It is an Act to control the import, ownership, production, transportation, storing, sale and utilization of poisons. Under this Act, no individual aside from the individual authorized under this 
Act is permitted to import poison from wherever outside Malaysia. Additionally, no individual will intentionally sell, supply, keep or store and transport any toxic substance otherwise than as per the guidelines made under this Act. Any preparation containing poisons only can be made as per the guidelines made under this Act. For the control of compounding of poisons substances for use in medicinal treatment, no individual will apportion, compound or blend any poison with any substance for treatment reason otherwise following any guidelines made under this Act [19].

Under this Act, it expressed that no poison will be sold by wholesaler aside from by an authorized distributer following the terms and states of his permit. Just the individual authorized to retail such toxin, a buyer outside Malaysia to whom such toxic substance is to be quickly sent out on sale; another authorized distributer; the proprietor or the owner of such business or for empowering such proprietor, or his officer following up for him, to agree to any prerequisites made by or under any aw in black and white regarding the medicinal treatment of people utilized on such estate; or an expert individual or tradesman with the end goal of such individual's or tradesman's occupation and not for resale; an enrolled medicinal professional or any registered dental specialist for the treatment of his patients or a veterinary specialist; an authorized drug specialist; a Government Department, local authority or public body; an emergency clinic, hospital, dispensary or veterinary emergency clinic kept up by the Government of Malaysia or State Government or by neighborhood authority or out of public funds or a charity affirmed by a request, regardless of whether general or exceptional, of the Director General of Health; an individual or foundation concerned about scientific research [13].

The wholesaler of any poisonous substance will not convey such substance until he has made or caused to be made a record in a book to be kept for such reason, in the endorsed structure, expressing the buyer's name and address, sale date, name and amount of the toxic substance provided and the reasons for which it is expressed by the buyer to be required; and the buyer has appended his sign to the record or has sent to the vender a signed prescription by the buyer and containing the data required to be entered under this subsection. The seller shall retain the written order and a reference to the record into the file [20]. In any case, for the situation when any toxic substance is required on urgent basis and it is difficult to acquire the sign of the buyer before administering it, the seller should express the explanations behind his activity to apportion the toxin without such signature and the date of dispensing in the book. Given that the seller need to get the written request signed by the buyer in regard of such sale, inside seven days of the date of sale. Under Section 16, which is about sale of toxic substances by retail and the individual with permit to sell such toxin by retail is only permitted to sell $[13,20]$.

\section{Medicines (Advertisement \& Sale) Act}

The objective of Medicine Advertisement Control is to regulate the content of the advertisement and to safeguard public healthiness by endorsing the rational use of medications. It is imperative to govern the publication of the unlawful advertisement or irresponsible advertisement which may mislead the consumers [21]. Under this Act, Section 3 states that advertisements stating any articles used as a medication, application or remedial measure for prevention or management or identification of specific ailments, contraception and improving heart or kidney functioning or sexual functioning of a human being is prohibited. The twenty diseases specified in Schedule include kidney disease, heart disease, epilepsy, Tuberculosis, leprosy, malignancy, deafness, asthma, paralysis, drug dependence, diabetes, hernia, eye infections, hypertension, psychological disorder, frigidity, impaired sexual function, infertility, venereal disease, and nervous incapacity or any ailment arising from or concerning sexual intercourse. Besides, under Section 4 , there is the proscription of advertisements related to abortion services and no individual shall publish any advertisement which its content can lead to procuring the miscarriage of females [22].

\section{Laws Governing the Sales and Marketing of Pharmaceutical Products}

\section{Prohibition of Sale to Person Under 18}

In Poison Act 1952, Section 17, the minimum age requirement for purchasing poison is eighteen years old. However, this age requirement does not apply to medical treatment purposes. In addition, anyone who violates this section can be legally charged for going against this Act. An individual who accidentally sold the poison to those less than eighteen years old should have a strong defence against charges made under this section where an individual had reasonable cause or strong evidence to consider that the sale was made to a person above the minimum age requirement, which is above eighteen years old. If the person fails to defend him or herself, then he or she will be charged under this offense [23].

\section{Sale of Poison by Wholesale}

Poison should not be sold by a wholesaler who does not have a license under section 15. A licensed wholesaler should fulfill the terms and conditions of his or her license which is clearly stated under section 26. The license that would be hold by a wholesaler is type A license that permits the license holder (a pharmacist) to be able to import, sale and stock normally by wholesale plus retail or solely by wholesale or retail. For a company to sell poison by wholesale, the type of license to be applied is type B license which authorizes them with the selling of such substance to the other company [19]. There are some exceptions of personnel or organization where a licensed wholesaler can sell or deliver their product. An authorized wholesaler can actually sell poison to another licensed retailer or wholesaler and a purchaser who is 
outside Malaysia where this poison is instantaneously exported. A licensed pharmacist, a Government Sector, local authority or public body, a hospice, infirmary, dispensary or veterinary hospital could also get the poison lawfully from the wholesaler. Moreover, an individual or institution can purchase the poison from the wholesaler legally with the intention of education, investigation or research [20].

The record of purchasing of poisons should be recorded clearly by making an entry into the Poison Book. In this Poison Book, the name and address of the purchaser, the date of the sale, the name and amount of the poison sold and the purposes of the poison to be used by the purchaser should be clearly stated in the prescribed form for record and reference purposes. The seller should make sure that the procurer has appended his signature to the entry in the poison book or has forwarded a prescription which confirms to the requirement as stated under Poison Act 1952, Section 15, subsection (3). If the poison is needed for emergency cases where the purchaser is unable to provide a signature or prescription before the poison is delivered to the hand of the purchaser, it is legally right for the seller to deliver the poison without purchaser's signature or prescription after making an entry in the poison book stating the rationale for his action and the date for delivery. However, the seller should take all the necessary steps as required by the law and the purchaser should forward a prescription in respect of such sale, within seven days of the date of delivery. For the purchaser who

Table 1: Different categories of Poisons. failed to do so, he or she will face legal charges for being guilty of an offense in contradiction of this Act. For the seller who sells or delivers some poison in contradiction to section 15 shall be charged on court [13].

\section{Sale of Poison by Retail}

As stated in section 16, which is subjected to section 18 , the sale of poison by retail should have type A license and in agreement with the terms and conditions stated. Sale of poison under section 16 requires immediate personal supervision of the individual who owned the license. The pharmacy assistant who works in the pharmacy needs to be supervised by the type A license owner when dispensing the poison. Whoever violates section 16 shall be filed for charges in court [13].

\section{Poison Book}

The dispensing of Group D Poison (Table 1) is regulated under Poison Book. Whenever Group D Poison is purchased by an individual, the particulars of the individual including signature and the amount of poison dispensed should be entered in the Poison Book. The purchaser of Group D Poison has to forward the written order to the pharmacist in charge when purchasing Group D Poison unless in emergency cases where the purchaser shall deliver the prescription within seven days after the purchase. Any individual who failed to do so shall be guilty of wrongdoing in contradiction of this Act [12].

\begin{tabular}{|c|c|}
\hline Group A Poisons & $\begin{array}{c}\text { Group A Poison is prohibited to be sold or delivered by wholesale with the } \\
\text { exception that the sale of such poison is by a licensed wholesaler who is } \\
\text { a pharmacist to a licensed pharmacist or to another licensed wholesaler } \\
\text { or immediately exported to a purchaser outside Malaysia, as clearly } \\
\text { expressed in section 20. Group A poison should only be supplied by a } \\
\text { licensed pharmacist. }\end{array}$ \\
\hline Group b poisons & $\begin{array}{l}\text { For Group B poisons to be dispensed, prescription with details of } \\
\text { medicines and patients must be presented to the pharmacist. The } \\
\text { signature of the pharmacist who dispensed the group B poison is } \\
\text { compulsory when supplying the poison. For special cases such as the } \\
\text { Group B Poison is needed urgently where prescription is not available } \\
\text { immediately, it is legally right for supplier or seller to sell or supply the } \\
\text { medicine without a prescription after recording in the prescription book, } \\
\text { upon taking instructions of a medical specialist verbally. However, the } \\
\text { patient should deliver a prescription within one day after the sale. }\end{array}$ \\
\hline Group C Poisons & $\begin{array}{l}\text { Proscription of sale or supply of Group C poison to any individual } \\
\text { except that this Group C poison is a dispensed medication or exists as a } \\
\text { component in a dispensed medication. For Group C Poison, the presence } \\
\text { of prescription during dispensing is not mandatory, but the pharmacist } \\
\text { should fill in the prescription book as record. }\end{array}$ \\
\hline Group D Poisons & $\begin{array}{l}\text { Group D poisons could only be sold or supply by a licensed pharmacist } \\
\text { to an individual whom he recognized personally or introduced by an } \\
\text { individual recognized personally to the pharmacist. Whenever Group D } \\
\text { poison is sold to an individual, the details of the purchaser and the aim } \\
\text { of buying this poison shall be stated clearly in the Poison Book. For cases } \\
\text { where the prescription is not delivered during the dispensing process, it } \\
\text { is legally right for a retailer to deliver the poison after an entry is made in } \\
\text { the Poison Book, provided that the purchaser present their prescription } \\
\text { within seven days after the sale. }\end{array}$ \\
\hline
\end{tabular}




\section{Prescription Book}

Any purchase of Group B and C Poison shall be made an entry to the Prescription Book. The details of the poison dispensed, and the name of the patient should be documented into the Prescription Book. The purchaser should forward the prescription within one day after purchase for any prescription which is given orally [13].

\section{Psychotropic Substance}

The psychotropic substance is adhered to specified laws and regulations under Poisons (Psychotropic Substances) Regulations 1989, in implementation of the powers discussed by section 30 of Poison Ordinance 1952. A person is prohibited from selling psychotropic substances unless sanctioned to be in ownership of these substances. Such substances should be obtained for legally right purposes and did not conflict with the rules and regulations stated under Poisons Regulation 1989 [23]. Only a number of people with certain professions would be accorded with the license in which the terms and conditions are under Regulation 15 to be in possession with the psychotropic substance. The profession who are given the authority are listed as below:-

a) A licensed pharmacist

b) A registered medicinal specialist

c) A registered dentist Division 1

d) A veterinary surgeon

e) The holder of a license issued under regulation 15

f) An individual who is working in any hospital where a psychotropic substance is used for treatment purposes in the ward and operating theatre

g) A person who is attached to scientific research or chemical analysis or educational activities

h) A community pharmacist

i) Customs officer, police officer or an officer of the posting unit only when they are carrying out their responsibility

\section{j) A Drug Enforcement Officer}

For controlling the import and export of psychotropic substances, it has its own specified rule and is not bounded to the Poison Act 1952. For the enforcement in the airport for psychotropic substance, the maximum quantities of poison as may be practically required for one month's usage by an individual, which have been legitimately supplied with the presence of prescription from a qualified medical practitioner. For import and export of psychotropic substance, one has to get authorization in Form A and Form C respectively. For export, the import certificate duly issued by the capable authority of the state of a psychotropic substance to be exported is needed. The fee for this import and export permission is 100 ringgit. Any individual who buy and use psychotropic substances need to present a permit which is valid for only twelve months. The fee for this permit shall be one hundred ringgit. Only a licensed pharmacist is allowed to dispense psychotropic substances $[17,24]$.

\section{Cosmetics}

The cosmetics product in Malaysia is controlled by the Control of Drugs and Cosmetics Regulation 1984. The production, selling, supply, possession, administration or importation of cosmetics must adhere strictly to the laws to assure the quality of the cosmetics product manufactured. A clear label that complies with the guidelines by the Director of Pharmaceutical Sciences should be attached to the products. For manufacturing of notified cosmetics by either personnel or premises must practice Good Manufacturing Practices (GMP) in order to ensure the sanitary condition. Quality check and regular inspection by the quality control department should be conducted to monitor the quality of the registered products [25].

\section{External Reference Pricing}

In recent news which stated that an external reference pricing applied to the pharmaceutical product would eventually lead to negative repercussion. Therefore, the Ministry of Health (MOH) would cooperate with the Ministry of Domestic Trade \& Consumer Affairs (MDTCA) to implement the controlling of medications price under the Price Control and Anti-Profiteering Act 2011. The serious concern of the pharmaceutical industry on this proposed implementation of regulations includes practice gaps [26]. The Pharmaceutical Association of Malaysia (PhAMA) is associated with the government's mission in progressive access of medicinal products to the public. The most significant flaws of this regulation are an unfair and inaccurate comparison of the external reference pricing due to the difference of market in the reference countries. Every country has its own market for the pharmaceutical products due to the burden of disease, symptoms, capacity to pay and market strategies [27]. Every country has its own pattern of diseases owed to which different medicines may be needed; likewise, the pattern of dispensing of medicines also varies from one medical practitioner to another. Thus, a single-payer healthcare system is inapt to be used as the standard for Malaysia's dichotomous health system. Next, an issue of discrimination against foreign companies occurs due to phased implementation of price controls on singlesource products that are usually patent-protected. Another issue arousing is that controlling the medications price would not resolve the basic matter of dropping healthcare costs. In short, external pricing reference brings more negative impact rather than positive outcomes [28].

\section{Inspection and Penalties}

For any renewal or releasing of a new license, the Licensing Officer would examine the premise and make sure that the 
inspection report is satisfying before releasing the license. A Drug Enforcement Officer would start to inspect and further examine the premise if they receive a complaint report from the public. The penalties for failing to keep any book or register or any false entry will be indictable by a fine not more than 5000 ringgit or custody not more than two years or both. An individual who is charged for offending this Act is indictable by a fine not more than 3000 ringgit or custody, not more than 1 year or both [29].

\section{Laws Governing the Advertising of Pharmaceutical Products}

\section{Standard of Promotion}

In Malaysia, the government is very strict when it comes to advertisements concerning medicine, since patients may be affected by undesired consequences. It is not rare to find a multitude of advertisements that say that their products work extremely well in the treatment of diabetes, obesity or cancer. This is especially true where alternative or conventional drugs are not checked and licensed by the authorities. In towns and villages, illegal posters and flyers that advertise "cure" against impotence are even more popular. Pharmacists should therefore, be aware of and ensure compliance with the laws governing medical advertising. If something bad happens, the pharmacist not only risks their profession but can also put customers who are buying the marketed drug in danger if they believe falsely about the advertising [30].

\section{Products Allowed to Be Advertised}

Only registered products by the Drug Control Authority (DCA) can be publicized such as lozenges, gums, and patches directed for nicotine replacement remedy with approval from the Medicine Advertisements Board (MAB). New Chemical Entities (NCE) can only be published once in press releases for products that meet the criteria, for instance, new medications that are accessible for the first time in Malaysia or within 18 months once marketed and there is no parallel drug revealed [31]

\section{Prohibited Claims}

Proscription of any promotion alluding to any article to prompt its utilization as a prescription, application or remedial measure with the intention of the prevention, management, mitigation, remedy or identification of ailments and conditions as the renal disease, asthma, cardiac disease, epilepsy, paralysis, leprosy, malignancies, deafness, drug dependence, diabetes, hernia, optical diseases, hypertension, tuberculosis, psychological, infertility, rigidity, weakening of the sexual function, venereal illness, nervous debility, or other complaint emerging from or involving sexual intercourse [32]. Advertisement ought not to encourage practicing contraception among people, improving the working of the human kidney or heart, or improving the sexual capacity and securing the miscarriage of women. Subsequently, any advertisements involving skill or service related to the management, prevention or identification of any sickness, infection, injury, disability affecting the body of human being; likewise capable of tempting any individual to pursue advice from the individual mentioned in the advertisement in association with such expertise or service is prohibited, unless the advertisement is approved by Minister or by Medicine Advertisements Board, by any private hospital or clinic or medical laboratory run by a registered medical specialist having a valid annual practicing permit under the Medical Act 1971 [33].

Therapeutic Claims: Therapeutic claims can be defined as cure or prevention of ailments of individuals other than those which are forbidden (20 diseases mentioned above), identifying disease or determining its level, varying the human anatomical structure, averting or modifying the normal functional status, either forever or for the time being, and whether by way of ending, delaying, speeding up that function. There are many types of claims that are not allowed to be advertised unless it is permitted by the Drug Control Authority (DCA). For instance, functional claims, claims related to anti-aging, intelligence, memorial and attentiveness, immunity against specific diseases, stress, performances in sports/ studies and weight- management products [34].

Product-Related Claims: Advertising shall not put emphasis on the features of a therapeutic product including flavor or beautifying traits to the level that customers may trust that the product is a food, cosmetic or other non-medicinal product. An advertisement should not contain inappropriate, overstated or ambiguous claims or illustrations to symbolize variations in the human body. Next, claims concerning product origin should give no extreme importance on encouraging the efficiency of a product by the producer or by the foreign country of origin. Other than that, herbal claims are not allowed unless they approved by DCA [35]. Furthermore, advertising should not recommend that a product's efficacy or safety is due, if not all its components occur naturally, to the statement that the product is 'natural'. If the product contains a single natural ingredient, the claim must be restricted to that ingredient only. In addition, for products having a natural approach to cure (bulk-laxatives), these products may state 'acts naturally'. For any product registered for greater than 18 months in Malaysia, the word "new" should not be included in the description. The word "new" is only appropriate to those products which have different registration number (MAL). Safety claims such as "No side effects", "No harmful effects", "and "No toxic or adverse effects" are forbidden [34].

Any claims related to specific pharmacokinetic are adequate only if authenticated by evidence or are specified in the permitted label. Measurement rules for once-a-day dosing don't positively imply that a case of 24-hour alleviation is sufficient. 'All day relief" claims are interpreted as meaning that the publicized impact keeps going up for in any event 10 hours for the duration of the day and 'all night relief' claims are interpreted as meaning that 
the promoted impact endures up for at least 8 hours during the night. Other than that, 'fast' claims are interpreted as meaning that the publicized impact happens within around 30 minutes while 'immediate' or 'instant' claims are interpreted as meaning that the promoted impact happens within around 10 seconds. 'Long-acting or sustained-release' claims are permitted distinctly for items with a sustained released detailing and furthermore '24-hour relief' is interpreted as meaning that the promoted impact keeps going as long as 24 hours (Board) [31].

\section{Standard of Morality or Decency}

No comment or graphical appearances should be given to ads that are likely to be perceived as inconsistent or insulting to or in some manner defamatory or degrading any section of the population in the ethical or decent standards prevalent in the Malaysian community (Board)[34].

\section{Acts of Violence}

No comments or graphic displays that can promote actions of violence, unlawful, or appear to be supportive of such acts or behaviour should be included in advertising (Board)[34].

\section{Denigration and Disparagement}

Under this law advertisements released should not disparage the products, advertisers or advertisements of other companies. Ads should not comprehend any declaration or statements which criticizes the medical profession or the significance of professional consideration. This applies to products as well whereby disgrace or dishonestly attacking other products, promoters or advertisements. However, evaluations of products can be made if they are from the identical registration holder if substantiated [35].

\section{Trust, Fear and Superstition}

Laws state that advertisements should not be done in a way that misuses the trust of the customer regarding the products. They should not advertise contents containing any statements or illustrations which would prompt fear of the observer that he is currently suffering from. Besides, advertisements should not be influencing consumer's superstitious beliefs in order to attract customers. The exploitation of religious belief(s) directly or by implication via advertisement should be avoided [33].

\section{Halal Logo / Statement}

It can be published in the advertisement for therapeutic products that have halal endorsement. Halal logo published in the advertisement should be verified by JAKIM or any other body which is accepted by JAKIM. The phrase "HALAL" must not be misused by advertisers. This includes any statements or pictorial related to Islamic religion such as the usage of the Quranic verses with the aim of confusing the consumers [36,37].

\section{Celebrity Endorsement}

Advertisement via celebrity endorsement should not deceive the consumer about the product being advertised either directly or by implication. When advertising with a celebrity authorization, it must be specified that "The effect of the product may vary among individuals"[35].

\section{Advertising on Internet}

It is a requirement for advertisers to clearly display KKLIU number on each page which has been permitted by Medicine Advertisements Board (MAB). Information including the name, contact number and address of the promoter must also be evidently specified on the page. In case the medication is being advertised collectively with other well-being products, advertisers must be careful as to not deceive the consumers and it is evidently distinguishable either permitted by MAB or advertisement that does not need the approval of MAB. Next, advertisements on websites in which their content is directed to healthcare professionals' access must be limited. Advertisers must state clearly that it is anticipated for healthcare professionals only $[25,38]$.

\section{Mandatory Statement and Warning Statement}

Next, each advertisement regarding pharmaceutical products must include the mandatory and warning statement. This is important to inform the public to be more cautious when using the products as medications; since they have the probability to benefit as well as produce detrimental effects if not used rationally. Every advertisement must contain an approved registration number by the Drug Control Authority (DCA) somewhere in the advertisement in a perfect way. The specimen of the statement that shall be inserted into the advertisement is "This is a medicine/supplement/ traditional product advertisement". For an auditory advertisement, it is adequate enough to mention: "This is a medicine advertisement approved by the Medicine Advertisements Board" [34,39].

Besides, there are also cautionary statements that are required to be inserted in the advertisement of certain products to avoid any unwanted occurrence. Advertisements for gums, lozenges and patches specified for nicotine replacement remedy must have the warning statement: "This product is not suitable for children. This product should not be used if you have serious heart disease, are pregnant or breastfeeding. Not to be used by non-smokers. Please consult the healthcare professional before using this product." Next, the weight loss products required cautionary statements such as: "This should be taken with a balanced diet and regular exercise" $[38,40]$.

\section{Conclusion}

Customers are always the final consumer to a pharmaceutical product and inappropriate governance may lead to their exposure towards adverse discrimination from the pharmacy or any 
pharmaceutical industry. The capability of the customers to assess the information provided in the promotion and differentiate the realities distributed in those unreliable articles diverges without a legitimate direction and guidelines. The activity of publicizing is worthy if they are in accordance with the enactment and rules provided by the respective authority. In fact, the public should be exposed to the advertisements which help the consumers to settle on level-headed choices on the utilization of medications without confounding, misdirecting and beguiling cases.

\section{References}

1. Haque A, Kabir SM, ANWAR AK, Yasmin F, MHM N, et al. (2019) Pharmaceutical Marketing Ethics in Healthcare Quality for Patient Satisfaction: An Islamic Approach. International J Pharmaceutical Research 11(1).

2. Marimuthu S (2016) Should Direct to Consumer Advertisements (DTCA) of Prescription Drugs Remain Banned in Malaysia? Australian Journal of Asian Law 17(1): 1-4.

3. Sisugoswami M, Al Shiibami AH, Nusari MS (2018) Attitude of physician towards gift acceptance from the representatives of pharmaceutical company and its impact on prescription pattern in Malaysia. International J on Recent Trends in Business and Tourism 2(2): 33-39.

4. Yazid AS, Ariffin J, Awang Z, Daud WN, Zainol FA, et al. (2017) Does Education Moderates the Relationship Between Decision Factors and Purchase Decision of Family Takaful Protection in Malaysia. World Applied Sciences J 35(9):1849-1863.

5. Ismail SF, Daud M, Jalil JA, Azmi IM, Safuan S, et al. (2018) Protecting Consumers from Misleading Online Advertisement for Herbal and Traditional Medicines in Malaysia: Are the Laws Sufficient. In $20186^{\text {th }}$ International Conference on Cyber and IT Service Management (CITSM).

6. Ting CY, Loo SC, Ting H, Ang WC, Jabar AH (2017) Compliance of community pharmacists and private general medical practitioners with Malaysian laws on poisons and sale of drugs. Therapeutic innovation regulatory science 51(4): 439-445.

7. Mohamad, Norhidayah (2018) A legal study on the effectiveness of Sale of Drugs Act 1952 and its regulations in controlling the sale of cosmetic products in Malaysia." PhD diss., Universiti Teknologi MARA.

8. Lee KS, Lim YW, Ming LC (2016) Can the New Pharmacy Bill safeguard patient's right in healthcare? Current Medicine Research and Practice 6(4): 167-168.

9. Ting CY, Loo SC, Sim ST, Tee EC, Hassali MA, et al. (2018) Unregistered Medical Products Detected by Malaysia's Pharmacy Enforcement Division During Routine Inspection: A Cross-Sectional Study among Selected Mainstream Medicines' Retailers in the State of Sarawak. Pharmaceutical Medicine 32(2): 143-148.

10. Lee YH, Arokiasamy L, Marn JT (2018) A Study on Ethical Customer Management and Organizational Sustainability in Pharmaceutical Industry in Malaysia. InSHS Web of Conferences EDP Sciences.

11. Zulkifli NW, Aziz NA, Hassan Y, Hassali MA, Bahrin NL, Ahmad A (2016) Are we on the right track?: overview of unregistered drugs in Malaysia. J Pharm Pract Community Med 2(4): 107-115.

12. Jusoh A, Kamarulzaman L, Zakaria Z (2016) The Implementation of Halal Cosmetic Standard in Malaysia: A Brief Overview. InContemporary Issues and Development in the Global Halal Industry.

13. Hassali MA, Shafie AA, See OG, Wong ZY (2016) Pharmacy practice in Malaysia. InPharmacy Practice in Developing Countries Academic Press 23-40.

14. Zulkifli NW, Yunus MA, Mustafa MF, En KW, Yee LC, et al. (2019) A Survey on Knowledge of Registered Drugs amongst Patients from the Specialist Clinic, Malaysia. Al Nahrain Journal of Science 22(3): 26-34.
15. Karim MS, Baba I, Shaffie F (2017) Dispute Law Model: Implications from the Implementation of Law on Kratom in Malaysia. Humanities, Arts and Social Sciences Studies Former name Silpakorn University J of Social Sciences Humanities Arts 17(1): 69-80.

16. Ariffin NM, Ghani AA (2019) Awareness on Substance Abuse among Universiti Utara Malaysia Students. Indian J of Public Health Res Development 10(3): 609-613.

17. Kamariah M (2019) Amendments to the Dangerous Drugs Act, 1952. Journal of Malaysian and Comparative Law 15: 131-158.

18. Kang S (2019) State Practice of Asian Countries in International Law. Malaysia InAsian Yearbook of International Law Brill Nijhoff. 273-277.

19. Mokhtar FS, Ismail R, Salleh AM, Ariffin ZZ (2016) Medical product liability in Malaysia: The need of legislative intervention. Social Sciences 11(21): 5162-5165.

20. Shafie AA, Hassali MA, Yahaya AH (2013) Health-Related Quality of Life among Nonprescription Medicine Customers in Malaysia. Value in health regional issues 2(1): 107-117.

21. Marimuthu S (2012) Regulation of the Advertising of Medicinal Products in Malaysia. The Malayan Law Journal.

22. Goh CF, Chan MY, Ali AM, Rashid SM (2019) The Complementary and Alternative Medicine (CAM) Product Information Brochure: How is Generic Structure Used to Persuade Potential Users? GEMA Online ${ }^{\circledR}$ Journal of Language Studies 19(4).

23. Kamarudin AR (2007) The misuse of drugs in Malaysia: Past and present Jurnal Anti Dadah Malaysia 1-24.

24. Babar ZU, Ibrahim MI, Hassali MA (2011) Pharmaceutical industry, innovation and challenges for public health: case studies from Malaysia and Pakistan. Journal of Pharmaceutical Health Services Research 2(4): 193-204.

25. Daud M, Jalil JA, Azmi IM, Ismail SF, Safuan S, et al. (2017) Unsafe nutraceuticals products on the Internet: The need for stricter regulation in Malaysia. In2017 5th International Conference on Cyber and IT Service Management (CITSM) 1-5.

26. Bekhet HA, Latif NW (2017) Highlighting innovation policies and sustainable growth in Malaysia. International Journal of Innovation, Management and Technology 8(3): 228-239.

27. Qamar M, Ahmad S, Poobalan K, Shaikh FA, Hammad MA (2017) Smoking Cessation Counseling: Perceptions and Barriers among Community Pharmacists. InUnity in Diversity and the Standardisation of Clinical Pharmacy Services: Proceedings of the 17th Asian Conference on Clinical Pharmacy (ACCP 2017) 28-30.

28. Fatokun O, Ibrahim MI, Hassali MA (2016) Generic medicines entry into the Malaysian pharmaceutical market. Generics and Biosimulars Initiative (GaBI) Journal 5: 180-181.

29. Ting CY, Ting H, Soh YC, Aaj AH, Lee KS (2017) Awareness of Custom Officers on Counterfeit Pharmaceutical Products and The Roles of Pharmacy Enforcement Officers. J of Young Pharmacists 9(2).

30. Aziz AA, Rahin NM, Asri NM (2019) Halal Advertising on Facebook: A Case Study of Health and Beauty Products in Malaysia. InManagement of Shari'ah Compliant Businesses 2019 177-192.

31. Mulinari S (2016) Unhealthy marketing of pharmaceutical products: An international public health concern. Journal of public health policy 37(2): 149-159.

32. Wartini S (2018) The legal implication of compulsory licence pharmaceutical products in the trips agreement to the protection of the right to health in developing countries. Jurnal Dinamika Hukum 18(1): $1-1$.

33. Lee YH, Arokiasamy L, Marn JT (2018) A Study on Ethical Customer Management and Organizational Sustainability in Pharmaceutical Industry in Malaysia. InSHS Web of Conferences EDP Sciences. 
34. Gleeson D, Lexchin J, Labonté R, Townsend B, Gagnon MA, et al. (2019) Analyzing the impact of trade and investment agreements on pharmaceutical policy: provisions, pathways and potential impacts. Globalization and health 15(1).

35. Lee KS, Lim YW, Ming LC (2016) The fate of the new pharmacy bill: going backwards or forwards?. Journal of pharmaceutical policy and practice $9(1)$.

36. Ngah AH, Thurasamy R (2018) Modelling the intention to adopt halal transportation among halal pharmaceutical and cosmetic manufacturers in Malaysia. Advanced Science Letters 24(1): 205-207.

37. Rayner TW, Taib MY, Abdullah R (2017) A Review of Halal Supply Chain in Malaysia: Pharmaceutical Cosmetics. In Pharmalogistik 203-212.

\section{ISSN: 2574-1241}

DOI: $10.26717 /$ BJSTR.2020.26.004357

Sadia Shakeel. Biomed J Sci \& Tech Res

(C) This work is licensed under Creative Submission Link: https://biomedres.us/submit-manuscript.php
38. Dawood OT, Hassali MA, Saleem F, Ibrahim IR (2018) Assessment of selfreporting reading of medicine's labels and the resources of information about medicines in general public in Malaysia. Pharmacology research perspectives $6(2)$

39. Pujari NM, Sachan AK, Kumari P, Dubey P (2016) Study of consumer's pharmaceutical buying behavior towards prescription and nonprescription drugs. J of Medical and Health Research. 1(3): 10-18.

40. See Wan O, Hassali MA, Saleem F (2018) Community pharmacists' perspectives of online health-related information: A qualitative insight from Kuala Lumpur, Malaysia. Health Information Management Journal 47(3): 132-139.

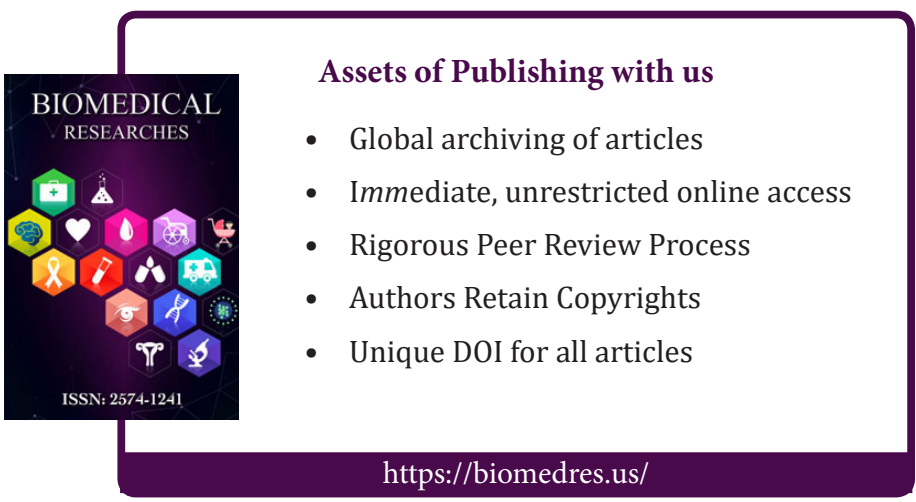

